\title{
Corporal Punishment: Risk Factors and Frequency among a Sample of Egyptian Children Attending Primary Care Centers
}

Shaymaa O. Khalil, ${ }^{1 *}$ Soheir H. El-Ghonemy, ${ }^{2}$ Ghada E. Amin, ${ }^{3}$ Maha M. Wahdan ${ }^{3}$

${ }^{1}$ Family Medicine department, Faculty of Medicine, Ain shams University

${ }^{2}$ Neuropsychiatry department, Faculty of Medicine, Ain Shams University

${ }^{3}$ Public Health department, Faculty of Medicine, Ain Shams University

\begin{abstract}
:
Background:Worldwide, the use of corporal punishment (CP) remains one of the most used methods to discipline children despite the empircial research on its negative outcomes. Objectives : (i) to identify the prevalence of CP (ii) to identify the sociodemographic risk factors (iii) to identify reasons for using CP, (iv) to assess mothers' knowledge about CP outcomes. Methods: Cross-sectional survey with a structured questionnaire was done on a sample of 298 Egyptian mothers of 2-14 years old children. Results: About (97\%) of children were corporally punished. The significant predictors of mothers' use of $\mathrm{CP}$ were low socio-economic class, child age mother age and mother's childhood experience of CP. Maternal stress, anger, seeking are the most common reasons.Conclusions: $\mathrm{CP}$ is prevelant problem in Egypt, yet it's predictable and adjustbale. Primary care practitioners should be trained to offer parenting guidance especially where there is other health care provider.

Keywords: corporal punishment, socio-demographics, reasons, knowledge.
\end{abstract}

\section{Introduction}

Although parents share strong feelings of love and concern for their children, the majority of them use physical punishment in order to correct their children's misbehaviors. ${ }^{(1)}$ United Nations Children's Fund (UNICEF) defined corporal punishment $(\mathrm{CP})$ as "any punishment in which physical force is used and intended to cause some degree of pain or discomfort, however light". (2) According to UNICEF, the prevalence of corporal punishment among 37 countries is $82 \%$ in children aged 214 years old. Egypt came at the top of the list of countries with $78 \%$ experienced physical punishment. ${ }^{(3)}$

Globally, Sweden was the first country to criminalize CP in 1979. Today, 51 countries achieved prohibition including only one Arab state, which is Tunisia. In Egypt, there is no prohibition in law at any setting. ${ }^{(4)}$ In June 2016, the national council for childhood and motherhood in co-operation with UNICEF launched the (Calm not Harm) campaign to increase public awareness about positive discipline. Many risk factors are associated with the use corporal punishment, such as a young parental age, ${ }^{(5)}$ male gender of the child, a low socio-economic status and parents having being physically punished during childhood. ${ }^{(6)}$

Corresponding author : E- mail: Shoka_255@yahoo.com 
Corporal punishment may secure immediate compliance but it is associated with negative effects on children's development that outweigh any probable benefit. ${ }^{(1)}$ It increases aggression towards peers ${ }^{(7)}$, depression and low self-esteem ${ }^{(6)}$, conduct disorders, ${ }^{(8)}$ disruptions in parent-child attachment, ${ }^{(9)}$ delay in cognitive development (10) and risk of escalation into physical abuse. ${ }^{(11)}$ It creates intergenerational cycle of violence as spanked children grow to be aggressive adolescents and then parents who used CP. ${ }^{(12)}$ Given the lack of studies on low and middle-income countries, we believe our study can make a significant contribution establishing the actual magnitude of the problem and its reasons to design preventive programs suitable for our cultural context.

The current study aimed to identify the prevalence of corporal punishment, socio-demographic risk factors and reasons for using corporal punishment. In addition, it aimed at assessing knowledge of mothers about corporal punishment outcomes.

\section{Methods:}

A cross-sectional study, was conducted at primary care centers of Saraya El Kobba and $6^{\text {th }}$ district Nasr City, as they are affiliated for research by Family Medicine department, over six months between May 2017 to November 2017. The calculated sample size was 298 participants depending on suggested frequency of corporal punishment among Egyptian children of $76 \%$ at $95 \%$ confidence interval using Epi Info7 program. It was inflated by $7 \%$ to be 320 participatants due to expected drop out. A total number of 320 Egyptian children of 2-14 years old were included.

According to UNICEF, this is the age group where CP was most prevalent and consequences were significant. Mothers of these children were interviewed to collect required data about their children. If mothers had more than one child in the prescribed age range, they were instructed to complete the study for the youngest child. Children who were proved to be physically abused depending on two questions in the beginning of questionnaire verifying need for medical intervention and intention to cause physical harm. Children who had chronic diseases were excluded where $\mathrm{CP}$ is used mostly among healthy children.

The study dependant variable was CP frequency and independent variables were child age, child gender, mother age, SES, mothers' attitudes, childhood experience of $\mathrm{CP}$ and knowledge score of CP outcomes. Socio-demographic 
characteristics (El-Shakhs, 1995), frequency of CP (Holden, 1993), Multiple Indicator Cluster Surveys (MICS 5) Discipline module (UNICEF, 2014), reasons that evoked mothers to use CP and mothers knowledge about CP outcomes (Designed using data from Taylor et al, 2011 and Greshoff, 2010) were examined. After translating the questionnaire; a pilot study was conducted on March 2017 including 30 participants ( $10 \%$ of total calculated sample), similar to those targeted by the study. They agreed to the clarity and length of the questionnaire (about 15 minutes).

Data entered was then analyzed using SPSS version 20. Data interpreted using an alpha $(\alpha)$ set at 0.05 and confidence interval of $95 \%$. ANOVA was done for comparing quantitative variables between the three categories of corporal punishment and p-value $\leq 0.05$ was considered significant. Qualitative data were expressed as frequencies (n) and percentage (\%). Chi-square was done for qualitative variable analysis and p-value $\leq 0.05$ was considered significant.

\section{Ethical consideration:}

Approval of the Research Ethical Committee of the Faculty of Medicine, Ain Shams University was obtained (FMASU MS 6/2017 on 24/01/2017). Consent was obtained by addressing all the steps of the study and the right to withdraw at any time.

\section{Results:}

Table (1) shows socio-economic status (SES) of the study population. The majority of participants are including in low intermediate SES (34.2\%) and high intermediate SES (25.8\%). Table (2) shows the frequency of CP usage. The prevelance of CP among study population is 97\%. Table (3) shows significant association between socio-economic status, mothers' age and child age with the usage of CP. Frequent CP usage is more common in low intermediate class (38.8\%) compared to infrequent usage group (27.0\%). Mean age of mother and child is lower in frequent usage group (child : $6.0+3.5$, mother: $29.9+5.8$ ) than in infrequent usage group (child : $6.9+3.8$, mother: $32.3+5.5$ ). There is no significant association between $\mathrm{CP}$ usage or child order or child gender.

Table (4) shows significant association between frequency of $\mathrm{CP}$ and discplinary methods used over past month mainly physical punishement. All methods of physical punishment were more common in frequent $\mathrm{CP}$ usage group vs. infrequent usage group. Shaking child and hitting on hand, arm or leg are the most common methods correlated with frequency of $\mathrm{CP}(\mathrm{P}=0.00)$. Shaking child are more higher in frequent 
CP usage group (81.5\%) vs. infrequent usage (50.5\%).Same for hitting on hand, arm or leg $(78.1 \%$ vs. $41.4 \%)$.

Table (5) demonstrates a significant association between mothers' attitudes and their childhood history of CP in relation to the frequency of CP usage with their children. Mothers of infrequent CP usage believed that it's not necessary to use physical punishment to raise their children (76.6\%) more than frequent usage group $(60 \%)$ and that there are other ways to educate the child (97.3\% vs. 89.3\%). History of experiencing $\mathrm{CP}$ as a child was more common in frequent usage group (81.5\%) when compared to infrequent usage group (64.9\%).

In table (6) there is a significant association between all of mothers' reasons for using CP and the frequency of CP usage with their children. All reasons are more common in frequent usage group when compared to infrequent usage. Yet, the most common causes in both group are stress $(80.9 \%, 63.1 \%)$ and anger $(74.7 \%, 60.4 \%)$ respectively. Surprisingly, the reason that least evoked mothers to use CP in both groups is their belief that $\mathrm{CP}$ had no alternative (34.3\% and 9\%). Table (7) shows significant association between mothers' knowledge score of CP outcomes and the frequency of $\mathrm{CP}$ usage with their children. The mean is higher in infrequent usage group vs. frequent usage group $(6.43 \pm 2.437$ vs. $5.43 \pm 2.367)$.

\section{Discussion:}

The aim of the current study is to estimate the prevalence of corporal punishment among a sample of Egyptian children. In addition, to identify the associated risk factors and reasons that led to increase using corporal punishment. Assessment of mothers' knowledge about CP outcomes was another objective. Our study found that using CP prevalence among Egyptian children between 2-14 years old is 97\%. We found that frequent usage ( $>2$ times per week) was more common $(59.7 \%$ ) when compared to infrequent use $(\leq 2$ times per week) group (37.3\%). These results were in concordance with studies conducted in Egypt $(78 \%)^{(3)}$ and $76.3 \%{ }^{(4)}$. Such agreement could be explained in the view of these researches have been done in similar cultural contexts.

While investigating the risk factors related to $\mathrm{CP}$, our study has found strong association between socio-economic status (SES) and the frequency of usage of CP. The higher the SES, the less frequent CP is used. Children from High intermediate SES have exposed to infrequent CP (36.9\%). While those from low and low intermediate SES have exposed to frequent CP (16.9 and 38.8\% respectively). Socio- 
economic status affects parenting through some determinants as emphasized by some authors as maternal education, ${ }^{(13)}$ financial hardship ${ }^{(14)}$ and higher levels of family conflict. $^{(15)}$

There was statistically significant relation between CP usage frequency and both child age and mothers' age. The frequency of using CP was higher with younger mothers or younger children. . The mean age of mothers who never used CP was 38.8 \pm 6.9 vs. the frequent usage $32.3 \pm 5.5$. The mean age of children with whom $\mathrm{CP}$ has never used was $8.2 \pm 3.3$ vs. $6.0 \pm 3.5$ years with frequent usage and $6.9 \pm 3.8$ with infrequent usage.

In our study, there no significant statistical finding regarding child gender in the prediction of the use of $\mathrm{CP}$. Yet, males were subjected more to $\mathrm{CP}$ in both frequent $\mathrm{CP}(57.3 \%)$ and infrequent $\mathrm{CP}$ usage group (58.6\%) when compared to females in frequent and infrequent groups respectively (42.7\% and $41.4 \%)$. These findings could be explained in the view of the socio-cultural background of Arab societies that views girls as weaker than boys and therefore require a softer approach. Such views has emphasized by other authors. ${ }^{(16)}$

Our study showed that used discipline methods are not limited to corporal punishment. Results revealed that mother using non-violent discipline was common in both frequent and infrequent CP usage group respectively for example taking away privileges $(86.0 \%$ and $83.8 \%)$ and Explaining why behavior is wrong $(85.4 \%$ and 90.1\%). While fewer reported psychological aggression for example shouting at child (84.8\% and $74.8 \%)$ and insulting child $(76.4 \%$ and $48.6 \%)$. There was statistical significant correlation between the frequency of using $\mathrm{CP}$ and using $\mathrm{CP}$ over past month.

Physical punishment like shaking child was more in frequent CP group (84.8\%) vs.. infrequent group (74.8\%), hitting on arm , hand or leg ( $78.1 \%$ vs. $41.4 \%)$. hitting on bottom (79.8\% vs. $28.8 \%)$ and hitting with an object (59.0\% vs. $14.4 \%)$. UNICEF survey findings on 2014 are consistent with our findings where non violent methods prevalence is higher than physical punishment in all of its forms. ${ }^{(3)}$ Other study in Egypt has inconsistent findings were beating child was more common (76.3\%) than taking away privileges $(39.3 \%)$ or yelling at child $(43.5 \%){ }^{(6)}$

Our findings could be explained in the view of $\mathrm{CP}$ is usually combined with other methods, such as withdrawal of privileges, reasoning. It could also be that mothers initially use non-violent discipline methods to correct children's misbehavior 
conduct, and when they do not achieve compliance, they use CP. (1) Further explanation is the detailed questionnaire was used to explore discipline methods where physical violence was explored in more than 5 forms not just beating the child.

The study has found significant association between mothers' attitudes and the frequency of $\mathrm{CP}$ usage with their children. Mothers who used CP infrequently had less positive attitudes toward CP. They believed that it's not necessary to use physical punishment to raise their children (76.6\%) and that there are other ways to educate the child $(97.3 \%)$ more than frequent CP usage group (60\% \& 89.3\%). Other studies stated that attitudes toward $\mathrm{CP}$ and positive expected outcomes are of the strongest predictors of its use. ${ }^{(17)}$ One study found that $84.6 \%$ of mothers who used CP had positive attitudes compared to only $46.7 \%$ of those who did not use CP. ${ }^{(18)}$ One of the explanations is that parents spank because that is what they know and because they believe it is an effective and irreplaceable practice. Parents engage in $\mathrm{CP}$ because they believe it to be a useful and appropriate disciplinary strategy. ${ }^{(16)}$

There was statistical significant association between mothers' childhood experience of $\mathrm{CP}$ and frequency of using $\mathrm{CP}$ by mothers. Higher percentage was found in the frequent usage group vs infrequent usage group to have childhood $\mathrm{cp}$ frequent experience ( $81.5 \%$ vs $64.5 \%$ ). As found by other studies that childhood experience of CP is associated with increased positive attitudes toward CP usage ${ }^{(18)}$ Despite recognizing corporal punishment as ineffective mothers may use CP as brain function pathways rely on primitive than cognitive behaviors learned during the preverbal years on in times of stress, frustration and fatigue. ${ }^{(19)}$

While investigating the reasons that evoked mothers to use related to $\mathrm{CP}$, our study has found maternal stress and anger were on top of the list. The more mothers approved stress as a reason, the higher frequency was the use of $\mathrm{CP}$, yet it was the most common cause in both infrequent and high frequency groups $(80.9 \%$ in high frequency group vs $63.1 \%$ in infrequent frequency group). Among parents who reported a high belief in corporal punishment higher parenting stress score (mean score $=212.71$ ), compared to parents with low levels of parenting stress (mean 60.71). (20) Consistent with our results, a research reported that parents who used CP, but also disapproved of its use, were less likely to use it to change a child's behavior and instead use it impulsively and out of anger. ${ }^{(18)}$ Marital dissatisfaction is another hidden component of stress, ${ }^{(21)}$ as it causes constricted emotions, and irritability, which can decrease parenting capacity and favoring of authoritarian parenting 
strategies to avoid triggering their partner's anger, or to displace their anger of their partner onto child. ${ }^{(21)}$

Another reason that was found to be statistically significant reason for using $\mathrm{CP}$ in our study was seeking obedience. It was more common reason in frequent $\mathrm{CP}$ usage group (75.3\%) compared to infrequent usage group (53.2\%). The current results goes with where the principal reason for using physical punishment was disobedience $(57.0 \%) .{ }^{(6)}$ This obedience is associated with less long-term compliance as immediate obedience is not internalized, it only occurs if the child perceives the threat of punishment to be found. ${ }^{(1)}$

While assesing mothers knowledge about CP expected outcomes, there was statistical significant association between their knowledege score and the frequency of using CP. The less frequent mothers used CP, the higher the knowledge score. Mean score in infrequent CP usage group was $6.43 \pm 2.437$ while in frequent group was $5.43 \pm 2.367$. Agreeing study showed that mean knowledge score is high in both group who used CP or not but it slightly lower in group that used physical punshiment (98.86) compared to group that did not used it (99.76). ${ }^{(17)}$ Results can be explained by studies that found CP was not favored by mothers but thought to be effective, similar to taking bad tasting medicine, it is not very pleasant but it works. ${ }^{(22)}$

\section{Study limitation:}

A cross-sectional study design does not allow for the establishment of causality. Yet, randomized controlled trials would be unethical to assign children to a group receiving painful treatment when research already suggests that such pain poses potential harm not outweighed by potential benefit.Assuming that $\mathrm{CP}$ is more prevelant among lower SES, multiple cluster sample including many governates would have been more informative. Sample was collected only from two primary care centers were most attendees were intermediare SES.

\section{Conclusion:}

In conclusion; corporal punishment is prevalent problem among Egyptian children (97\%). Most common method of CP was shaking the child. Many reasons evoked mothers to use $\mathrm{CP}$, stress, anger and inability to control emotions were on top of the list.

\section{Conflict of interest}

There was no conflict of interest in the current study 


\section{References}

1. Gershoff E. Corporal punishment by parents and associated child behaviors and experiences: A meta-analytic and theoretical review. Psychological Bulletin. 2002;128(4):539-579.

2. United Nations Children's Fund (UNICEF) . Convention on the Rights of the Child: General Comment No. 8. UNICEF: Geneva, Switzerland. 2006. Available from: https://www.unicef.org/crc/ . Accessed August 2017.

3. United Nations Children's Fund(UNICEF). A statistical analysis of violence against children, Multiple Indicator Cluster Surveys (MICS 5), New York. 2014. Available at

http://files.unicef.org/publications/files/Hidden_in_plain_sight_statistical_analysis_ EN_3_Sept_2014.pdf . Accessed at August 25, 2016.

4. Global Initiative to End All Corporal Punishment of Children Ending legalised violence against children. global progress, 2015. Available at www.endcorporalpunishment.org/resources/global-reports/global-report-2015.html. Accessed at Januray 2017.

5. Combs-Orme T, Cain D. Predictors of mothers' use of spanking with their infants. Child Abuse and Neglect. 2008;32(6):649-657.

6. Abolfotouh M, El-Bourgy M, Seif El Din A, Mehanna A. Corporal punishment: Mother's disciplinary behavior and child's psychological profile in Alexandria, Egypt. Journal of Forensic Nursing. 2009;5(1):5-17.

7. MacKenzie M, Nicklas E, Waldfogel J, Brooks-Gunn J. Corporal Punishment and Child Behavioural and Cognitive Outcomes through 5 Years of Age: Evidence from a Contemporary Urban Birth Cohort Study. Infant and Child Development. 2011;21(1):3-33.

8. Pasalich D, Dadds M, Hawes D, Brennan J. Do callous-unemotional traits moderate the relative importance of parental coercion versus warmth in child conduct problems? An observational study. Journal of Child Psychology and Psychiatry. 2011;52(12):1308-1315.

9. Coyl D, Roggman L, Newland L. Stress, maternal depression, and negative motherinfant interactions in relation to infant attachment. Infant Mental Health Journal. 2002;23(1-2):145-163.

10. Straus M, Paschall M. Corporal Punishment by Mothers and Development of Children's Cognitive Ability: A Longitudinal Study of Two Nationally Representative Age Cohorts. Journal of Aggression, Maltreatment and Trauma. 2009;18(5):459-483.

11. Orhon F, Ulukol B, Bingoler B, Gulnar S. Attitudes of Turkish parents, pediatric residents, and medical students toward child disciplinary practices. Child Abuse and Neglect. 2006;30(10):1081-1092.

12. Thornberry T, Knight K, Lovegrove P. Does Maltreatment Beget Maltreatment? A Systematic Review of the Intergenerational Literature. Trauma, Violence, and Abuse. 2012;13(3):135-152.

13. Morawska A, Winter L, Sanders M R. Parenting knowledge and its role in the prediction of dysfunctional parenting and disruptive child behaviour. Child: Care, Health and Development. 2009; 35, 217-226.

14. Morawska A, Winter L, Sanders M. Parenting knowledge and its role in the prediction of dysfunctional parenting and disruptive child behaviour. Child: Care, Health and Development. 2009;35(2):217-226.

15. Bøe T, Sivertsen B, Heiervang E, Goodman R, Lundervold A, Hysing M. Socioeconomic Status and Child Mental Health: The Role of Parental Emotional 
Well-Being and Parenting Practices. Journal of Abnormal Child Psychology. 2013;42(5):705-715.

16. Davidov M, Khoury-Kassabri M. Recollections of harsh discipline in childhood and depressive feelings in adulthood: The roles of culture and gender. Children And Youth Services Review. 2013;35(6):1007-1014.

17. Ateah C, Durrant J. Maternal use of physical punishment in response to child misbehavior: implications for child abuse prevention. Child Abuse And Neglect. 2005;29(2):169-185.Gagné M, Tourigny M, Joly J, Pouliot-Lapointe J. Predictors of Adult Attitudes Toward Corporal Punishment of Children. Journal of Interpersonal Violence. 2007;22(10):1285-1304.

18. Perry BD. Maltreated children: Experience, brain development, and the next generation. New York: W. W. Norton and Company. 1996.

19. Parke RD, Collmer C. Child abuse: An interdisciplinary analysis. In E. M. Hetherington (Ed.), Review of child development research Chicago: University of Chicago Press. 1975; (5) 509-590.

20. Crouch J, Behl L. Relationships among parental beliefs in corporal punishment, reported stress, and physical child abuse potential. Child Abuse \& Neglect. 2001;25(3):413-419. Parke, R. D., and Collmer, C. Child abuse: An interdisciplinary analysis. In E. M. Hetherington (Ed.), Review of child development research Chicago: University of Chicago Press. 1975; (5) 509-590.

21. Levendosky A, Graham-Bermann S. Parenting in Battered Women: The Effects of Domestic Violence on Women and Their Children.Journal of Family Violence. 2001;16(2):171-192.

22. Robinson D, Funk D, Beth A, Bush A. Changing Beliefs About Corporal Punishment: Increasing Knowledge About Ineffectiveness to Build More Consistent Moral and Informational Beliefs. Journal of Behavioral Education. 2005;14(2):117139. 
Table (1): Socio-demographic Characteristics of the study population

\begin{tabular}{|c|c|c|}
\hline Socio-demographic Characteristics & $\mathbf{N}$ & $\%$ \\
\hline $\begin{aligned} \text { Gender } & \\
\text { - } & \text { Male } \\
\text { - } & \text { Female }\end{aligned}$ & $\begin{array}{l}171 \\
127\end{array}$ & $\begin{array}{l}57.4 \% \\
42.6 \%\end{array}$ \\
\hline $\begin{aligned} & \text { SES } \\
& \text { - } \text { Very low } \\
& \text { - Low } \\
& \text { - low intermediate } \\
& \text { - Intermediate } \\
& \text { - high intermediate } \\
& \text { - High } \\
& \text { - Very high }\end{aligned}$ & $\begin{array}{c}15 \\
41 \\
102 \\
56 \\
77 \\
7 \\
0\end{array}$ & $\begin{array}{c}5.0 \% \\
13.8 \% \\
34.2 \% \\
18.8 \% \\
25.8 \% \\
2.3 \% \\
0.0 \%\end{array}$ \\
\hline Mother age & $\begin{array}{c}31.0 \pm 6.0 \\
\text { Mean } \pm \text { SD }\end{array}$ & $\begin{array}{l}19.0-50.0 \\
\text { Min - Max }\end{array}$ \\
\hline Child age & $\begin{array}{c}6.4 \pm 3.6 \\
\text { Mean } \pm \text { SD }\end{array}$ & $\begin{array}{c}2.0-14.0 \\
\text { Min - Max } \\
\end{array}$ \\
\hline
\end{tabular}

Table (2): Frequency of using CP per week of the study population

\begin{tabular}{|l|l|l|}
\hline Frequency of using CP per week & N & \% \\
\hline Never had CP & 9 & $3.0 \%$ \\
\hline Infrequent usage ( $\leq$ 2/week) & 111 & $37.3 \%$ \\
\hline Frequent usage (> 2 / week) & 178 & $59.7 \%$ \\
\hline
\end{tabular}


Table (3): Socio-demographic characteristics in relation to frequency of using CP

\begin{tabular}{|c|c|c|c|c|c|c|c|c|c|}
\hline \multicolumn{2}{|c|}{$\begin{array}{l}\text { Socio-demographic } \\
\text { Characteristics }\end{array}$} & \multirow{2}{*}{\multicolumn{2}{|c|}{$\begin{array}{l}\begin{array}{l}\text { Never } \\
\text { had CP }\end{array} \\
\%\end{array}$}} & \multicolumn{2}{|c|}{$\begin{array}{l}\text { Infrequent } \\
\text { usage }\end{array}$} & \multicolumn{2}{|c|}{$\begin{array}{l}\text { Frequent } \\
\text { usage }\end{array}$} & \multirow[t]{2}{*}{$\mathbf{X}^{2}$} & \multirow[t]{2}{*}{ P-value } \\
\hline & & & & $\mathbf{N}$ & $\%$ & $\mathbf{N}$ & $\%$ & & \\
\hline \multirow[t]{2}{*}{ Gender } & Male & 4 & $44.4 \%$ & 65 & $58.6 \%$ & 102 & $57.3 \%$ & \multirow[t]{2}{*}{.679} & \multirow[t]{2}{*}{0.712} \\
\hline & Female & 5 & $55.6 \%$ & 46 & $41.4 \%$ & 76 & $42.7 \%$ & & \\
\hline \multirow{4}{*}{$\begin{array}{l}\text { Child } \\
\text { order }\end{array}$} & Youngest & 3 & $33.3 \%$ & 42 & $37.8 \%$ & 48 & $27.0 \%$ & \multirow[t]{4}{*}{6.912} & \multirow[t]{4}{*}{0.329} \\
\hline & Oldest & 3 & $33.3 \%$ & 36 & $32.4 \%$ & 61 & $34.3 \%$ & & \\
\hline & $\begin{array}{l}\mathrm{He} \text { is the only } \\
\text { child }\end{array}$ & 2 & $22.2 \%$ & 11 & $9.9 \%$ & 34 & $19.1 \%$ & & \\
\hline & Other & 1 & $11.1 \%$ & 22 & $19.8 \%$ & 35 & $19.7 \%$ & & \\
\hline \multirow[t]{7}{*}{ SES } & Very low & 0 & $0.0 \%$ & 4 & $3.6 \%$ & 11 & $6.2 \%$ & \multirow[t]{7}{*}{40.366} & \multirow[t]{7}{*}{$0.000 *$} \\
\hline & Low & 5 & $55.6 \%$ & 6 & $5.4 \%$ & 30 & $16.9 \%$ & & \\
\hline & $\begin{array}{l}\text { Low } \\
\text { intermediate }\end{array}$ & 3 & $33.3 \%$ & 30 & $27.0 \%$ & 69 & $38.8 \%$ & & \\
\hline & Intermediate & 0 & $0.0 \%$ & 24 & $21.6 \%$ & 32 & $18.0 \%$ & & \\
\hline & $\begin{array}{l}\text { High } \\
\text { intermediate }\end{array}$ & 1 & $11.1 \%$ & 41 & $36.9 \%$ & 35 & $19.7 \%$ & & \\
\hline & High & 0 & $0.0 \%$ & 6 & $5.4 \%$ & 1 & $0.6 \%$ & & \\
\hline & Very high & 0 & $0.0 \%$ & 0 & $0.0 \%$ & 0 & $0.0 \%$ & & \\
\hline $\begin{array}{l}\text { Mother } \\
\text { age }\end{array}$ & \multicolumn{2}{|l|}{$\begin{array}{l}38.8 \pm 6.9 \\
\text { Mean } \pm \text { SD }\end{array}$} & \multicolumn{2}{|c|}{$\begin{array}{l}32.3 \pm 5.5 \\
\text { Mean } \pm \text { SD }\end{array}$} & \multicolumn{3}{|c|}{$\begin{array}{l}29.9 \pm 5.8 \\
\text { Mean } \pm \text { SD } \\
\end{array}$} & $\begin{array}{l}14.416 \\
F\end{array}$ & $0.000 *$ \\
\hline $\begin{array}{l}\text { Child } \\
\text { age }\end{array}$ & $\begin{array}{l}8.2 \pm 3.3 \\
\text { Mean } \pm \text { SD }\end{array}$ & & \multicolumn{2}{|c|}{$\begin{array}{l}6.9 \pm 3.8 \\
\text { Mean } \pm \text { SD }\end{array}$} & \multicolumn{3}{|c|}{$\begin{array}{l}6.0 \pm 3.5 \\
\text { Mean } \pm \text { SD }\end{array}$} & $\begin{array}{l}3.404^{* * *} \\
\mathrm{~F}\end{array}$ & $0.035^{*}$ \\
\hline
\end{tabular}

* Significant at a level of $\leq 0.05 \%$

Table (4): Disciplinary methods used during last monrh in relation to frequency of using CP:

\begin{tabular}{|l|l|l|l|l|l|l|l|l|}
\hline \multirow{2}{*}{} & \multicolumn{2}{|l|}{$\begin{array}{l}\text { Never } \\
\text { used CP }\end{array}$} & \multicolumn{2}{l}{$\begin{array}{l}\text { Infrequent } \\
\text { usage }\end{array}$} & \multicolumn{2}{l}{$\begin{array}{l}\text { Frequent } \\
\text { usage }\end{array}$} & \multirow{2}{*}{$\mathrm{X}^{2}$} & \multirow{2}{*}{$\begin{array}{l}\text { P- } \\
\text { Value }\end{array}$} \\
\cline { 2 - 9 } & $\mathrm{N}$ & $\%$ & $\mathrm{~N}$ & $\%$ & $\mathrm{~N}$ & $\%$ & & \\
\hline - & 7 & $77.8 \%$ & 93 & $83.8 \%$ & 153 & $86.0 \%$ & .619 & 0.734 \\
\hline $\begin{array}{l}\text { Explained why behavior } \\
\text { wrong }\end{array}$ & 7 & $77.8 \%$ & 100 & $90.1 \%$ & 152 & $85.4 \%$ & 2.007 & 0.367 \\
\hline - Shake child & 0 & $0.0 \%$ & 56 & $50.5 \%$ & 145 & $81.5 \%$ & 49.175 & $0.00^{*}$ \\
\hline - Shout or yell at child & 6 & $66.7 \%$ & 83 & $74.8 \%$ & 151 & $84.8 \%$ & 5.550 & 0.062 \\
\hline $\begin{array}{l}\text { Gave child something else to } \\
\text { do }\end{array}$ & 7 & $77.8 \%$ & 84 & $75.7 \%$ & 146 & $82.5 \%$ & 1.986 & 0.370 \\
\hline - Hit on bottom with bare hand & 0 & $0.0 \%$ & 32 & $28.8 \%$ & 142 & $79.8 \%$ & 86.058 & $0.00^{*}$ \\
\hline - Hit using an object & 0 & $0.0 \%$ & 16 & $14.4 \%$ & 105 & $59.0 \%$ & 62.668 & $0.00^{*}$ \\
\hline Insult child/ call him dumb etc & 1 & $11.1 \%$ & 54 & $48.6 \%$ & 136 & $76.4 \%$ & 34.206 & $0.00^{*}$ \\
\hline Hit on face, head, ears & 0 & $0.0 \%$ & 15 & $13.5 \%$ & 67 & $37.6 \%$ & 23.476 & $0.00^{*}$ \\
\hline Hit on hand, arm or leg & 0 & $0.0 \%$ & 46 & $41.4 \%$ & 139 & $78.1 \%$ & 54.200 & $0.00^{*}$ \\
\hline Hit as hard as possible & 0 & $0.0 \%$ & 1 & $0.9 \%$ & 32 & $18.0 \%$ & 21.401 & $0.00^{*}$ \\
\hline
\end{tabular}

$*$ Significant at a level of $\leq 0.05 \%$ 
Table (5): Mothers' attitude and their childhood history of $\mathrm{CP}$ in relation to frequency of using $\mathrm{CP}$

\begin{tabular}{|c|c|c|c|c|c|c|c|c|}
\hline \multirow{2}{*}{ Mothers' attitude } & \multicolumn{2}{|c|}{$\begin{array}{c}\text { Never had } \\
\text { CP }\end{array}$} & \multicolumn{2}{|c|}{$\begin{array}{c}\text { Infrequen } \\
\text { t usage }\end{array}$} & \multicolumn{2}{|c|}{$\begin{array}{c}\text { Frequent } \\
\text { usage) }\end{array}$} & \multirow{2}{*}{$\mathbf{X}^{\mathbf{2}}$} & P \\
\cline { 2 - 8 } & $\mathbf{N}$ & $\mathbf{\%}$ & $\mathbf{N}$ & $\mathbf{\%}$ & $\mathbf{N}$ & $\mathbf{\%}$ & & \\
\hline $\begin{array}{l}\text { Mothers' attitude } \\
\text { - CP is needed to raise child } \\
\text { properly }\end{array}$ & 1 & $11.1 \%$ & 26 & $23.4 \%$ & 71 & $39.9 \%$ & 10.390 & $0.006 *$ \\
\hline $\begin{array}{l}\text { Believe there are other ways to } \\
\text { discipline a child }\end{array}$ & 9 & $\begin{array}{c}100.0 \\
\%\end{array}$ & 108 & $97.3 \%$ & 159 & $89.3 \%$ & 7.093 & $0.029 *$ \\
\hline $\begin{array}{l}\text { Mothers history of having CP during } \\
\text { their childhood }\end{array}$ & 4 & $44.4 \%$ & 72 & $64.9 \%$ & 145 & $81.5 \%$ & 14.103 & $0.001 *$ \\
\hline
\end{tabular}

* Significant at a level of $\leq 0.05 \%$ 
Table (6): Reasons for using CP in relation to frequency of using CP:

\begin{tabular}{|c|c|c|c|c|c|c|c|c|}
\hline & & & & & & & \multirow[t]{3}{*}{$\mathrm{X}^{2}$} & \multirow[t]{3}{*}{$\mathrm{P}$} \\
\hline & \multicolumn{2}{|c|}{$\begin{array}{l}\text { Never used } \\
\mathrm{CP}\end{array}$} & \multicolumn{2}{|c|}{$\begin{array}{l}\text { Infrequent } \\
\text { usage }\end{array}$} & \multicolumn{2}{|c|}{ Frequent usage } & & \\
\hline & $\mathrm{N}$ & $\%$ & $\mathrm{~N}$ & $\%$ & $\mathrm{~N}$ & $\%$ & & \\
\hline - $\quad$ To obey my orders & 1 & $11.1 \%$ & 59 & $53.2 \%$ & 134 & $75.3 \%$ & 26.640 & $0.000 *$ \\
\hline $\begin{array}{l}\text { - To show respect for } \\
\text { me }\end{array}$ & 1 & $11.1 \%$ & 44 & $39.6 \%$ & 124 & $69.7 \%$ & 32.963 & $0.000 *$ \\
\hline $\begin{array}{l}\text { To learn the } \\
\text { acceptable behavior }\end{array}$ & 1 & $11.1 \%$ & 61 & $55.0 \%$ & 138 & $77.5 \%$ & 28.971 & $0.000 *$ \\
\hline $\begin{array}{ll}\text { Attacking another } \\
\text { child }\end{array}$ & 0 & $0.0 \%$ & 39 & $35.1 \%$ & 92 & $51.7 \%$ & 14.881 & $0.001 *$ \\
\hline - Telling lies & 0 & $0.0 \%$ & 32 & $28.8 \%$ & 102 & $57.3 \%$ & 29.982 & $0.000^{*}$ \\
\hline - Low grades in exams & 1 & $11.1 \%$ & 35 & $31.5 \%$ & 82 & $46.1 \%$ & 9.188 & $0.010^{*}$ \\
\hline $\begin{array}{lll}\text { - } & \begin{array}{l}\text { Cannot } \\
\text { emotions }\end{array} & \text { control } \\
\end{array}$ & 1 & $11.1 \%$ & 64 & $57.7 \%$ & 132 & $74.2 \%$ & 20.835 & $0.000 *$ \\
\hline - $\quad$ Mother anger & 1 & $11.1 \%$ & 67 & $60.4 \%$ & 133 & $74.7 \%$ & 19.837 & $0.000 *$ \\
\hline - $\quad$ Mother stress & 0 & $0.0 \%$ & 70 & $63.1 \%$ & 144 & $80.9 \%$ & 34.387 & $0.000^{*}$ \\
\hline $\begin{array}{l}\text { - Seeking immediate } \\
\text { compliance }\end{array}$ & 1 & $11.1 \%$ & 54 & $48.6 \%$ & 113 & $63.5 \%$ & 13.849 & $0.001 *$ \\
\hline $\begin{array}{l}\text { - Others ways are not } \\
\text { effective }\end{array}$ & 1 & $11.1 \%$ & 30 & $27.0 \%$ & 100 & $56.2 \%$ & 27.651 & $0.000 *$ \\
\hline $\begin{array}{l}\text { - Other ways did not } \\
\text { work. }\end{array}$ & 1 & $11.1 \%$ & 31 & $27.9 \%$ & 106 & $59.6 \%$ & 32.120 & $0.000 *$ \\
\hline - There is no alternative & 0 & $0.0 \%$ & 10 & $9.0 \%$ & 61 & $34.3 \%$ & 26.940 & $0.000 *$ \\
\hline $\begin{array}{l}\text { Mother isn't skilled } \\
\text { using other ways }\end{array}$ & 0 & $0.0 \%$ & 19 & $17.1 \%$ & 51 & $28.7 \%$ & 7.910 & $0.019 *$ \\
\hline
\end{tabular}

Table (7): Mothers' knowledge about CP outcomes in relation to frequency of using CP:

\begin{tabular}{|l|c|c|c|c|c|c|c|}
\hline & $\mathrm{N}$ & Mean \pm SD & \multicolumn{2}{|c|}{$95 \%$ CI for Mean } & \multirow{2}{*}{$\begin{array}{c}\text { Min - } \\
\text { Max }\end{array}$} & F & P \\
\cline { 3 - 6 } & & & $\begin{array}{c}\text { Lower } \\
\text { Bound }\end{array}$ & $\begin{array}{c}\text { Upper } \\
\text { Bound }\end{array}$ & & \\
\hline - Never had CP & 9 & $6.33 \pm 1.871$ & 4.90 & 7.77 & $4-9$ & 6.303 & $0.002^{*}$ \\
\hline $\begin{array}{l}\text { Infrequent } \\
\text { usage }\end{array}$ & 111 & $6.43 \pm 2.437$ & 5.97 & 6.89 & $0-9$ & & \\
\hline - Frequent usage & 178 & $5.43 \pm 2.367$ & 5.08 & 5.78 & $0-9$ & & \\
\hline
\end{tabular}

* Significant at a level of $\leq 0.05 \%$ 


\section{الملخص العربي}

\section{العقاب البدني : معدل انتثار وعوامل الخطورة في عينة من الاطفال المصريين في مراكز الرعاية الاولية}

شيماء اسامة خليل1 ، سهير حلمي الغنيمي² ، غادة عصام الدين أمين3 ، مها مجدي و هدان3.

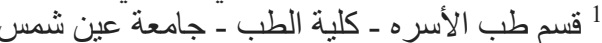

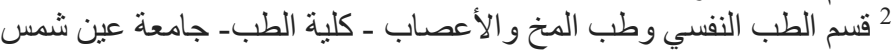



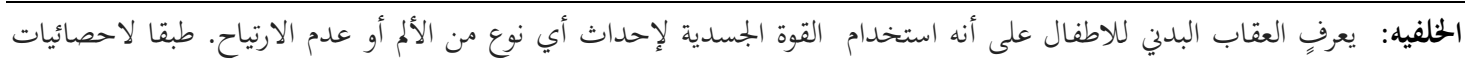

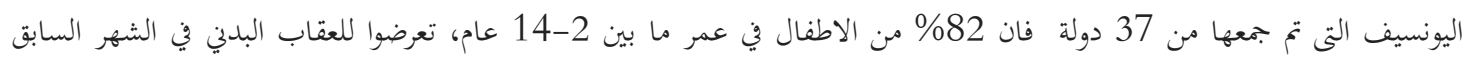

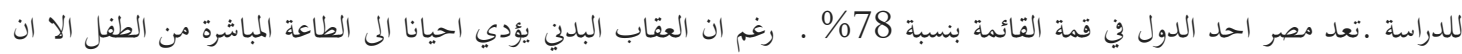

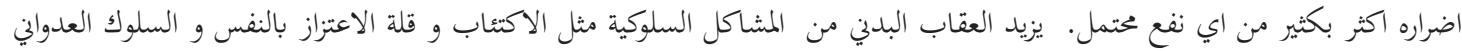

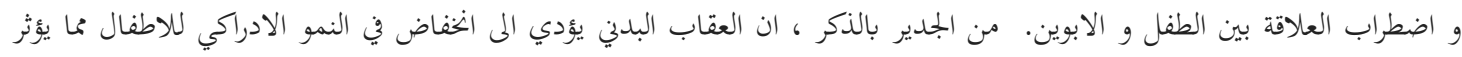

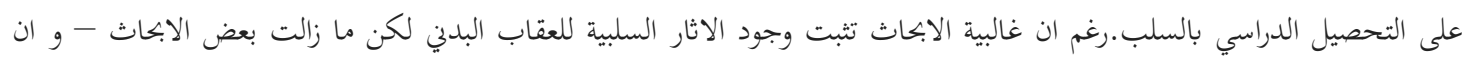

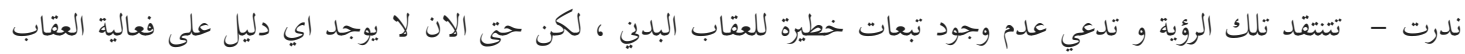

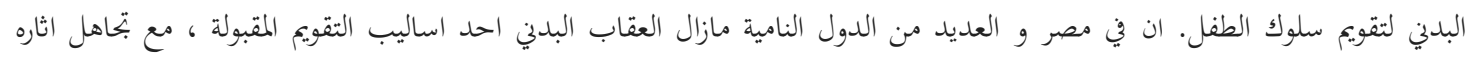

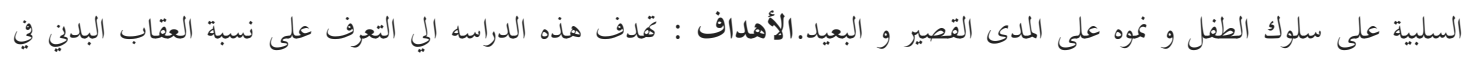

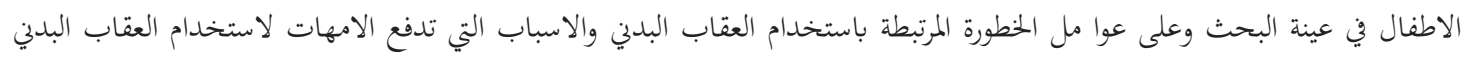
وكذا تقييم مدى معرفة الامهات بالنتائج السلبية لاستخدام العقاب البدني. المنهجية و طرق البحث: دراسة تحليلية مقطعية تم اجرائها بين

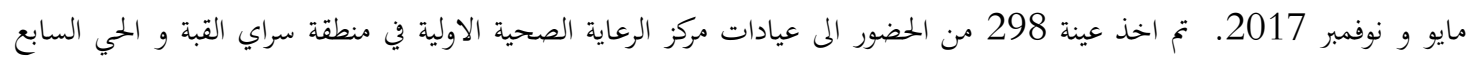

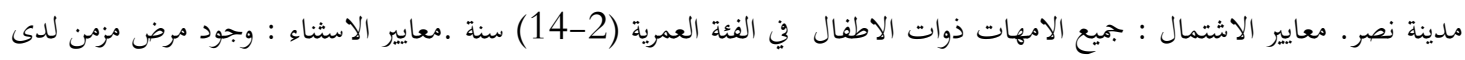

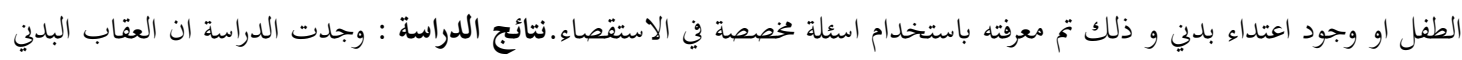

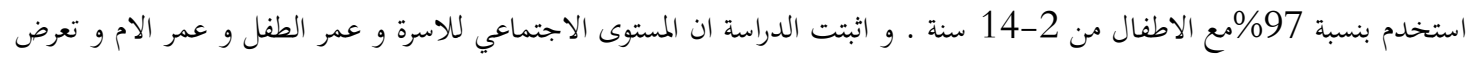

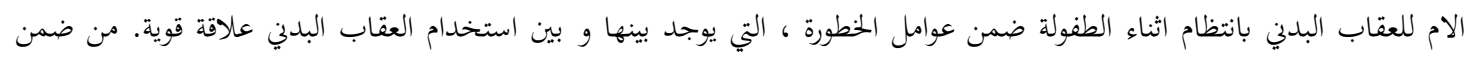

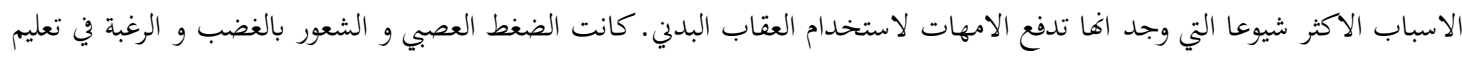

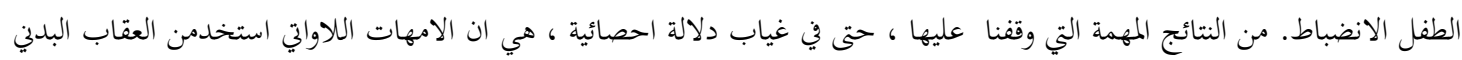

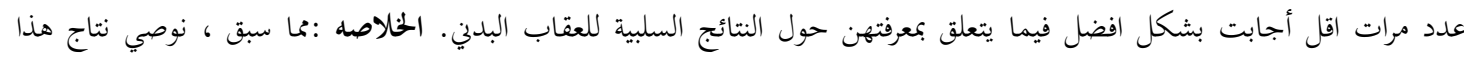

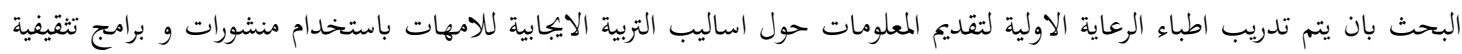

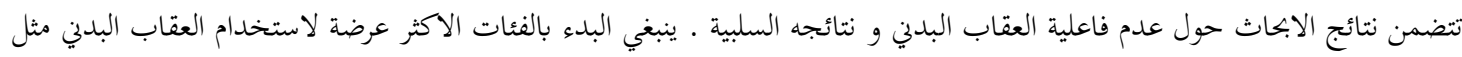
الطبقات الاجتماعية المنخفضة و الامهات الاصغر سنا و الاطفال الاصغر سنا و الامهات اللاواتي تعرضن للعقاب البدني اثناء طفولتهن 